Article

\title{
Establishment of the Underlying Rationale and Description of a Cheap Nanofiltration-Based Method for Supplementing Desalinated Water with Magnesium Ions
}

\section{Liat Birnhack *, Oded Nir and Ori Lahav}

Faculty of Civil and Environmental Engineering, Technion-Israel Institute of Technology, Haifa 32000, Israel; E-Mails: odednir3@gmail.com (O.N.); agori@tx.technion.ac.il (O.L.)

* Author to whom correspondence should be addressed; E-Mail: birbirit@tx.technion.ac.il; Tel.: +972-4-8292627; Fax: +972-4-8295696.

Received: 14 March 2014; in revised form: 15 April 2014 / Accepted: 16 April 2014 /

Published: 5 May 2014

\begin{abstract}
The importance of supplying drinking water with a balanced mineral composition, including a minimal concentration of $\mathrm{Mg}$ (II) ions, has been recently acknowledged by many publications, as well as in official WHO guidelines. The issue is relevant to naturally occurring soft waters and lately to the rapidly increasing volume of supplied desalinated water. This paper presents an enhancement of a recently developed nanofiltration-based method for the selective separation of soluble $\mathrm{Mg}$ (II) species from seawater. The generated rich- $\mathrm{Mg}$ (II) brine is demonstrated to be suitable for supplementing soft waters with magnesium ions. The brine, generated using a commercial membrane (DS-5 DL, Osmonics) at various operational conditions is characterized by high $\mathrm{Mg}$ (II) concentrations ( $\sim 8.5 \mathrm{~g} / \mathrm{L})$ and low $\mathrm{Cl}: \mathrm{Mg}$ and $\mathrm{Na}: \mathrm{Mg}$ molar concentration ratios (1.6 and 0.6 , respectively, at 28-bar operation). A food-grade antiscalant is dosed to the feed seawater to prevent scaling; however, since the $\mathrm{Mg}(\mathrm{II})$ concentration in the brine is high, for attaining $10 \mathrm{mg} \mathrm{Mg} / \mathrm{L}$ of desalinated water, the dilution ratio with the desalinated water is $\sim 1: 850$, resulting in maximal additional concentrations of 0.024 antiscalant, $34.9 \mathrm{Cl}(-\mathrm{I})$, $12.9 \mathrm{Na}(\mathrm{I}), 0.05 \mathrm{Sr}$ (II) and $0.003 \mathrm{~B}$ (all concentrations in $\mathrm{mg} / \mathrm{L}$ ). The overall cost of $1 \mathrm{~kg}$ of $\mathrm{Mg}(\mathrm{II})$ separated by the presented process amounts to between $\$ 0.05$ and $\$ 0.07$, i.e., much cheaper than the estimated costs of alternative processes for $\mathrm{Mg}(\mathrm{II})$ addition to desalinated water.
\end{abstract}


Keywords: nanofiltration; post-treatment; desalination; magnesium ion; drinking water; cost assessment; water quality

\section{Introduction}

\subsection{Health Risks Associated with Low Mg(II) Concentrations in Drinking Water}

Throughout the years, epidemiologic studies have implied that low concentrations of magnesium ions $(\mathrm{Mg}(\mathrm{II}))$ in drinking water may be associated with several significant health risks (e.g., type 2 diabetes, metabolic syndrome, hypertension, sudden cardiac death, several cancer types, and more [1,2]). However, an unambiguous linkage has not been established, and the protective mechanism of $\operatorname{Mg}$ (II) ions has not been identified. Despite this, in 2009, the World Health Organization (WHO) concluded in an official document that "there is growing consensus among epidemiologists that the epidemiological evidence, along with clinical and nutritional evidence, is already strong enough to suggest that new guidance should be issued" [1]. In view of this statement, the WHO thus recommended maintaining a minimum $\mathrm{Mg}(\mathrm{II})$ concentration of $10 \mathrm{mg} / \mathrm{L}$ in all drinking waters [1].

Desalinated water is a rising water source in which the $\mathrm{Mg}(\mathrm{II})$ concentration is usually close to zero, even after the re-mineralization step, which typically aims at replenishing calcium ions (Ca(II)) and carbonate alkalinity to the water. Following the WHO recommendation, the Israeli Ministry of Health decided in 2011 on the addition of $\mathrm{Mg}$ (II) to desalinated water to a level of $20-30 \mathrm{mg} \mathrm{Mg} / \mathrm{L} \mathrm{[3]}$; however, $\mathrm{Mg}(\mathrm{II})$ addition has not, do-date, been implemented in Israel. Following the 2009 WHO recommendation, several epidemiological studies were published, which supported the request for replenishing $\mathrm{Mg}$ (II) in desalinated water: For example, Chiu et al. (2010) [4] conducted matched cancer case-control studies to investigate the relationship between the risk of cancer occurrence and drinking water quality, including $\mathrm{Mg}$ (II) content; the study showed that the risk of pancreatic cancer associated with high tri-halo-methane (THM) levels was elevated among cases with lower $\operatorname{Mg}$ (II) intake from drinking water. The authors suggested that $\mathrm{Mg}(\mathrm{II})$ may act similarly to folate, which has already been proven mechanistically to have a protective effect against cancer. Correspondingly, it was shown that $\mathrm{Mg}$ (II) levels in drinking water modified the effects of THM on the risk of colon cancer development [5]. Moreover, drinking water $\mathrm{Mg}$ (II) intake apparently modifies the effect of exposure to nitrate in drinking water and the associated increased risk of mortality attributed to esophageal cancer [6]. $\mathrm{Ca}$ (II) and $\mathrm{Mg}$ (II) intake from drinking water may reduce the risk of gastric cancer occurrence related to the exposure of a high concentration of nitrate in drinking water [7]. A clear trend of a decreased risk of lung cancer in women with elevated $\mathrm{Mg}$ (II) levels was also observed [8].

Other studies showed the positive effect of drinking water $\mathrm{Mg}$ (II) with respect to additional health related aspects: for example, $\mathrm{Mg}$ (II) may have a positive role against hip fractures, according to the inverse association between drinking water magnesium concentration and the risk of hip fracture in both genders observed in Norway [9]. It may have a positive effect on blood pressure, as reflected by the comparison of individuals from some Serbian municipalities having different drinking water $\mathrm{Mg}(\mathrm{II})$ concentrations. This comparison showed that diastolic blood pressure was the lowest in 
subjects from the district with the highest drinking water $\mathrm{Mg}(\mathrm{II})$ concentration $(42 \mathrm{mg} / \mathrm{L}$, compared to $11 \mathrm{mg} / \mathrm{L})$ [10]. Low levels of magnesium in drinking water can aggravate liver damage from alcohol [11]. In addition, results supporting the theory of a link between soft water and the pathogenesis of osteoporosis were presented [11]. Consumption of low-mineral bottled water (TDS of $1.2-10.9 \mathrm{mg} / \mathrm{L}$ and hardness of $2.3-0.8 \mathrm{mg} / \mathrm{L}$ as $\mathrm{CaCO}_{3}$ ) is associated with higher levels of CVD biomarkers, serious pathological lesions of the heart and aortic arch in rabbits (following 12 month of low mineral water consumption) and an increased level of Hcy and a deteriorated lipid profile in young men (after 30 days of low mineral water consumption) [12].

In addition to these health related findings, it should be recognized that a low concentration of $\mathrm{Mg}(\mathrm{II})$ in drinking water has a significant inverse impact on the overall $\mathrm{Mg}$ (II) intake, as demonstrated by Spungen et al. [13], who compared the total $\mathrm{Mg}$ (II) and $\mathrm{Ca}(\mathrm{II})$ intake (i.e., the intake from both food and drinking) of individuals living in areas in which different water sources were supplied, including an area supplied by desalinated water. According to their results, the $\mathrm{Mg}$ (II) and $\mathrm{Ca}$ (II) intakes may be significantly lower among individuals consuming desalinated water than among individuals consuming water from conventional or mixed sources. The latter results corroborate the recommendation to replenish desalinated water with $\mathrm{Mg}(\mathrm{II})$ and $\mathrm{Ca}(\mathrm{II})$.

To conclude, there are publications that imply that magnesium intake does not necessarily protect against cardiovascular disease and coronary heart disease. However, the majority of relevant studies, including some endorsed by the WHO, show evidence of statistically significant inverse association between $\mathrm{Mg}^{2+}$ concentrations in drinking water and cardiovascular mortality.

\subsection{Other Aspects Associated with Low Mg(II) Levels in Irrigation Water}

A valuable water source allocated for agricultural irrigation should include a minimum $\operatorname{Mg}($ II) concentration, required in order to minimize the need for the application of fertilizers, particularly in case the local soil is low in minerals [14] and no other water sources containing these components are continuously available. Yermiyahu et al. (2007) [15] stated that even if such water sources are available (i.e., high mineral water sources) and are planned to be mixed with the desalinated water, to minimize fluctuations in the quality of the supplied water, the mineral content of the desalinated water should approach the content of the other sources. Otherwise, the farmer will have to install and operate sophisticated and expensive control systems to flatten fluctuations. The addition of adequate concentrations of these minerals to the desalinated water in the desalination plant may circumvent the need for adding them through fertilizers.

With respect to the health impact of irrigating with water low in $\mathrm{Mg}(\mathrm{II})$, it has been noted that the decreasing mineral content in high-yield grains, as observed since the Green Revolution, has coincided in time with rising global mortality rates from cardiovascular diseases. This suggests that irrigating with low $\mathrm{Mg}$ (II) waters results in low $\mathrm{Mg}$ (II) intake from cultivated crops, which, in turn, may be associated with elevated cardiovascular mortality over the past 50 years [16]. Finally, it is noted that in arid areas of the world, such as Israel and parts of Spain and Australia, a considerable portion of treated wastewater is reused for agricultural irrigation. Thus, low $\mathrm{Mg}$ (II) concentration in drinking water eventually leads to low $\mathrm{Mg}(\mathrm{II})$ concentration in irrigation water [17]. 
1.3. Description of a Cheap and Very Simple Process for Enriching Desalinated Water with Mg(II) (As Well As Ca(II) and $\mathrm{SO}_{4}(-\mathrm{II})$ ) Through the Dosage of Seawater Nanofiltration Retentate

This paper describes new results of a recently developed method [18] for separating $\mathrm{Mg}(\mathrm{II})$ ions from seawater in a fashion that maximizes the $\mathrm{Mg}$ (II) concentration in the target solution, while at the same time minimizes the addition of the unwelcome seawater species $\left(\mathrm{Cl}^{-}, \mathrm{Na}^{+}, \mathrm{B}, \mathrm{Br}^{-}\right.$, etc. $)$to the receiving desalinated or soft water. The process is schematically depicted in Figure $1 . \operatorname{The} \mathrm{Mg}(\mathrm{II})$ separation method is based on passing seawater through suitable nanofiltration (NF) membranes in a way that: (1) enhances the separation between divalent and monovalent ions, i.e., rejects the divalent ions, while allowing monovalent ions to pass the membrane; and (2) generates brine with the highest $\mathrm{Mg}(\mathrm{II})$ concentration possible. Since the solution dosed to the desalinated water is the brine of the NF step, pathogens initially present in seawater will remain in the seawater NF brine. Thus, in order to prevent the contamination of the desalinated water, the NF brine is passed through an ultrafiltration membrane, prior to its introduction to the desalinated water. Note that the bacteria and protozoa retention of ultrafiltration (UF) membranes is very high (6-log attenuation [19]), while virus retention is moderate (it can reach 6-log removal, but often a removal below 1-log is reported [19]). Therefore, it can be assumed that the brine dosed to the desalinated water contains no bacteria and protozoa, but it may contain viruses. However, since disinfection is normally applied to the product water prior to distribution, the viruses that might have passed the UF membrane would be removed by the disinfection step.

As the brine is produced, food-grade antiscalant (e.g., Genesys CAS, manufactured by Genesys International, [20]) is dosed to the feed water in order to prevent $\mathrm{CaCO}_{3}$ and $\mathrm{CaSO}_{4}$ precipitation and subsequent chemical fouling of the membrane. Previous studies [18,21] showed that operating the NF step at high recovery ratios was beneficial in the sense that it reduced the ratio between the unwanted ions (namely $\mathrm{Cl}(-\mathrm{I})$ and $\mathrm{Na}(\mathrm{I})$ ) and the desired ions (namely $\mathrm{Mg}(\mathrm{II})$ ) in the brine. The produced $\mathrm{NF}$ $\mathrm{Mg}(\mathrm{II})$-rich brine is ultimately used as the $\mathrm{Mg}(\mathrm{II})$ ion source at the post-treatment stage in the desalination plant. Naturally, such a supplementary step can be combined with any conventional post-treatment process and is not limited to calcite dissolution, which was arbitrarily shown as the $\mathrm{Ca}$ (II) and alkalinity addition technique in Figure 1. Moreover, the investigated NF-based $\mathrm{Mg}$ (II) addition process can be integrated also into the treatment of other soft water types, and not exclusively to reverse osmosis (RO) desalinated water. As compared with previous methods suggested for $\mathrm{Mg}$ (II) addition to desalinated waters at the post treatment stage [22-25], the current approach is less selective in the sense that the $\mathrm{Mg}$ (II) supplied to the water is accompanied by a certain (not very high) concentration of (mainly) $\mathrm{Na}^{+}$and $\mathrm{Cl}^{-}$, but on the other hand, it is simpler in operation and (as shown at the end of this paper) much cheaper than any other (reasonable) alternative.

\section{Experimental Section}

\subsection{Experimental Apparatus}

NF experiments were carried out using a pilot-scale seawater desalination unit comprising one 4" spiral wound NF module. The experimental system included two pumps, a booster pump (centrifugal) and a high pressure pump (positive displacement), as well as a titanium heat exchanger and a chiller 
for maintaining a constant temperature of $25 \pm 1{ }^{\circ} \mathrm{C}$. In addition, the system includes flow meters for the permeate and the brine streams, a 25-micron filter to protect the high-pressure pump, pressure and temperature gauges and a pressure regulator spring valve. All tubing, fittings and wetted parts in the equipment are stainless steel made. In the experimental setup, the concentrate stream was continuously recycled back to the feed tank, which initially consisted of $200 \mathrm{~L}$ of typical Mediterranean seawater. The permeate stream was collected in a different tank, which was placed on a scale for the purpose of accurately determining the recovery ratio at any given time during the run. Once a desired recovery ratio was attained, the permeate stream was directed to the feed tank, and the system was allowed to stabilize in a full recirculation mode for a minimum of $20 \mathrm{~min}$. Samples were then collected from the feed tank (representing the cumulative brine concentrations), the permeate tank (representing the accumulative permeate concentrations) and from the brine and permeate pipes, representing the momentary brine and permeate concentrations, respectively.

Figure 1. Schematic representation of the $\mathrm{Mg}(\mathrm{II})$ enrichment process, based on seawater nanofiltration (NF) separation.

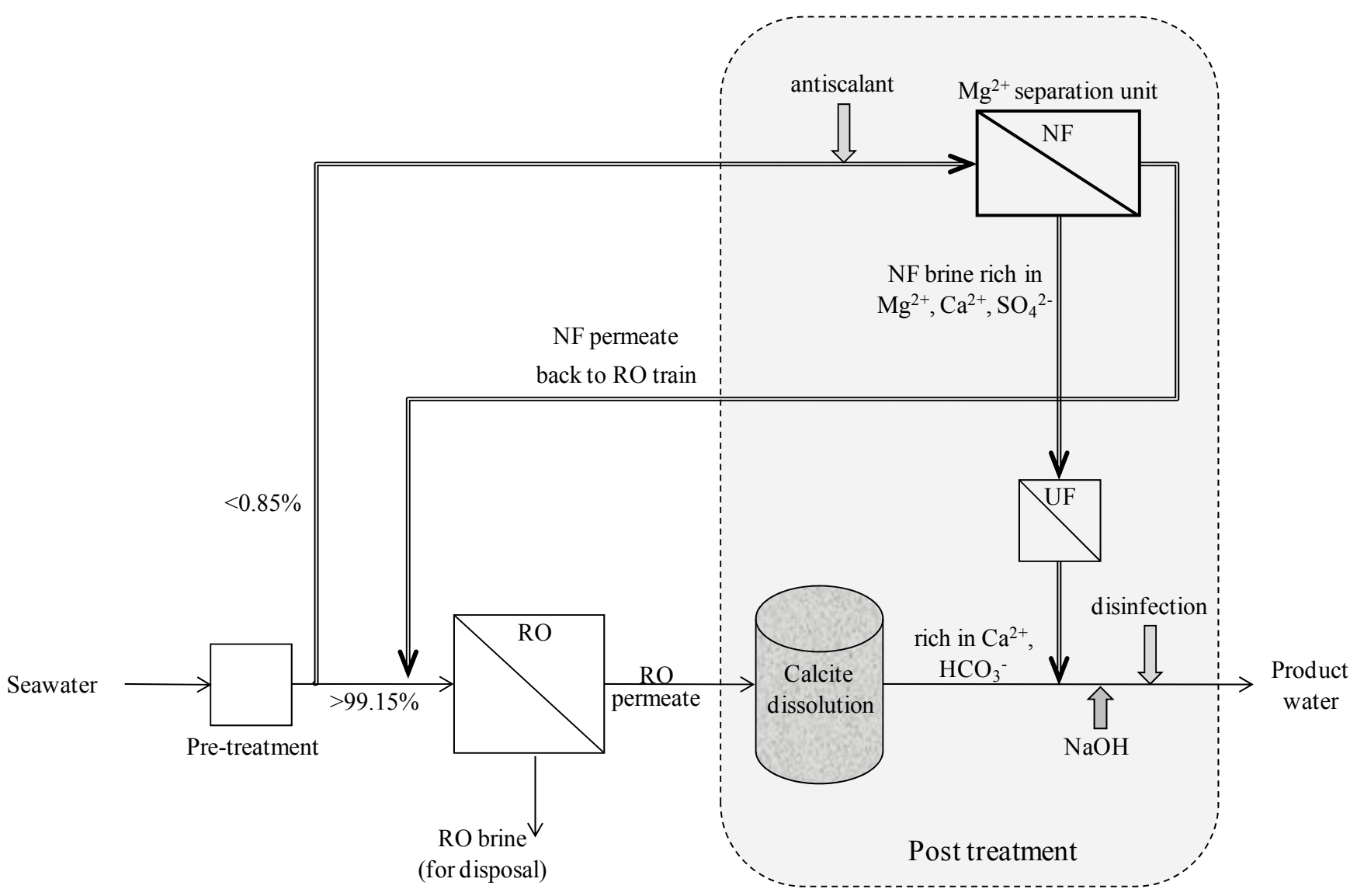

\subsection{Calculations}

Two types of solute rejection values (denoted r) are presented and discussed in this paper: (1) the "overall rejections" (that is, the rejection values calculated based on the initial feed concentration of the solute $\left(\mathrm{C}_{\mathrm{Feed}}\right)$ and its accumulative permeate concentration $\left.\left(\mathrm{C}_{\mathrm{P} \text { accu }}\right)\right): \mathrm{r}=1-\mathrm{C}_{\mathrm{P} \text { accumulate }} / \mathrm{C}_{\mathrm{Feed}}$; and (2) the "momentary rejection" (that is, the solute rejection at a specific time, or specific recovery, 
calculated based on the momentary permeate solute concentration $\left(\mathrm{C}_{\mathrm{P}} \mathrm{t}\right)$ and the solute concentration on the feed side of the membrane at the specific time).

In the next sections, unless otherwise specified, the overall rejections are presented and discussed.

\subsection{Analyses}

The samples were characterized by Inductively Coupled Plasma-Atomic Emission Spectroscopy (ICP-AES) (1CAP6300 Duo, Thermo Scientific) for the determination of the following ion concentrations: $\mathrm{Ca}^{2+}, \mathrm{Mg}^{2+}, \mathrm{Na}^{+}, \mathrm{SO}_{4}{ }^{2-}, \mathrm{K}^{+}, \mathrm{B}, \mathrm{Sr}^{2+}$. In addition, chloride concentrations were determined using the argentometric method, according to standard methods [26].

\section{Results and Discussion}

\subsection{Resultant Water Quality}

Dosing NF brine for enriching desalinated water with $\mathrm{Mg}(\mathrm{II})$ unavoidably introduces other components to the product water. Thus, the composition of the produced brine was analyzed under various conditions in order to identify the most advantageous NF process operational conditions, from the desalinated water quality standpoint. Figure 2 presents the $\operatorname{Mg}$ (II) rejections (overall rejections) recorded with three applied pressures and a wide range of recovery ratios. As observed from Figure 2, considerably higher rejection values were achieved when the applied pressure was increased from 10 to 18 bar, while only slight improvement was apparent in the rejection values when the pressure was further increased to 28 bar. Consequently, at the higher pressure values, a smaller volume of seawater is required in order to separate the required $\mathrm{Mg}$ (II) mass. Moreover, the dilution effect when dosing the brine to the desalinated water is reduced when the pressure is increased, because the brine's $\mathrm{Mg}(\mathrm{II})$ concentrations are elevated: 7.707, 7.892 and $8.520 \mathrm{~g} \mathrm{Mg} / \mathrm{L}$ at 10,18 and 28 bar, respectively (at a recovery of $85 \%$ ). From the quality aspect of the product desalinated water, another important factor is the concentration ratios between unwanted seawater ions (mainly $\mathrm{Cl}(-\mathrm{I})$ and $\mathrm{Na}(\mathrm{I})$ ) and the target ion $(\mathrm{Mg}(\mathrm{II})$ ), which are shown in Figure 3. From Figure 3, it can be concluded that decreasing the pressure from 28 bar to 10 bar had a negligible effect on the $\mathrm{Na}$ (I) to $\mathrm{Mg}$ (II) and on the $\mathrm{Cl}(-\mathrm{I})$ to $\mathrm{Mg}(\mathrm{II})$ molar concentration ratios. Note that for technical reasons, the recovery ratio in the experiments was not increased beyond $90 \%$. Therefore, only the $\mathrm{Na}$ (I) and $\mathrm{Cl}(-\mathrm{I})$ to $\mathrm{Mg}$ (II) concentration ratios presented in Figure 3 at recovery ratios below 90\% are calculated based on the concentrations measured in the brines, while the points representing the concentration ratios at $95 \%$ recovery are theoretically shown, by way of extrapolation. The $95 \%$ recovery ratio points (full symbols) were derived from the approximate linear slopes of the measured points (empty symbols). Thus, these points are merely estimations, which still need to be proven. The theoretically calculated points suggest that such an elevation of the recovery ratio would reduce the $\mathrm{Cl}(-\mathrm{I})$ to $\mathrm{Mg}(\mathrm{II}) \mathrm{molar}$ ratio to $1.80,1.67$ and 1.57 at 10,18 and 28 bar, respectively; that is, below the $\mathrm{Cl}(-\mathrm{I})$ additions resulting from pure $\mathrm{MgCl}_{2}$ dosage. With respect to the $\mathrm{Na}$ (I) to $\mathrm{Mg}$ (II) ratio, it would be reduced to 0.650 .74 and 0.67 , at the 10,18 and 28 bar scenarios, respectively. 
Figure 2. $\operatorname{Mg}(\mathrm{II})$ rejection values at 10,18 and 28 bar $(\Delta, \circ$ and + , respectively) as a function of the recovery ratio.

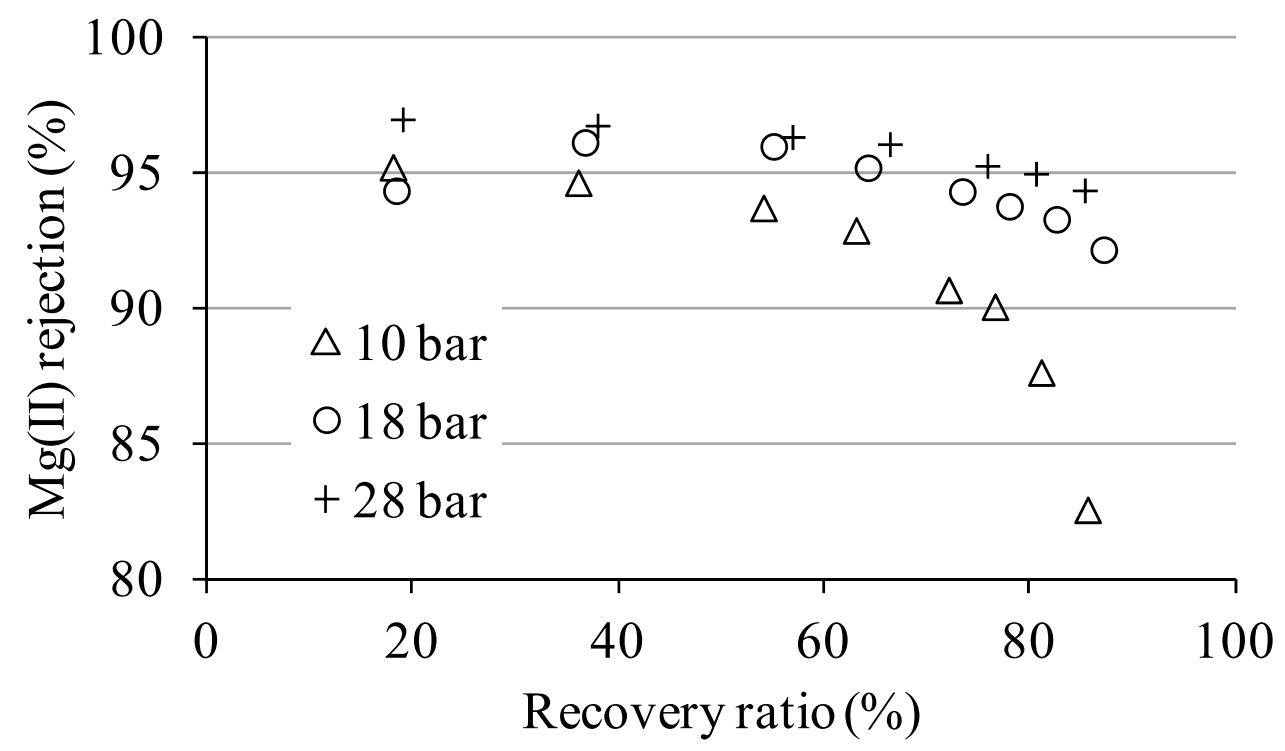

Figure 2 shows that the rejection of $\mathrm{Mg}$ (II) by the NF membrane deteriorated with the recovery value, as expected. The same trend was observed for all other ions, i.e., the reduction in rejection as the recovery ratio was increased. However, the results shown in Figure 3 are a consequence of differences in the extent of the reduction of the rejection with the recovery, for both $\mathrm{Mg}(\mathrm{II})$ and the monovalent ions $(\mathrm{Cl}(-\mathrm{I})$ and $\mathrm{Na}(\mathrm{I}))$. In other words, at high concentrations (i.e., high recovery ratios), the rejection values for all ions decrease. However, the rejection of $\mathrm{Mg}(\mathrm{II})$ is reduced in a moderate manner, while the rejections of the monovalent ions $(\mathrm{Cl}(-\mathrm{I})$ and $\mathrm{Na}(\mathrm{I}))$ decrease more steeply. This phenomenon (which has already been observed in previous studies, e.g., [18]) implies that the governing filtration mechanism is such that the momentary rejection of $\mathrm{Mg}$ (II) declines in a lesser fashion as a result of the increase in concentration in the feed side of the membrane. It is apparent that the rejections of $\mathrm{K}(\mathrm{I})$ and $\mathrm{Na}(\mathrm{I})$ deteriorated more sharply (from rejections of around $4 \%$ to negative rejection below $-5 \%$ for $\mathrm{Na}(\mathrm{I})$ and $\mathrm{K}(\mathrm{I})$, values varying significantly from experiment to experiment, i.e., 10, 18 and 28 bar) than the rejection of $\mathrm{Mg}$ (II) (which was reduced from $97.0 \%$ to $94.4 \%$ in the 28 bar experiment, for example). The decrease in the total rejection of $\mathrm{Mg}$ (II) may be completely attributed to increased $\mathrm{Mg}(\mathrm{II})$ concentration in the retentate side and the decreased flux, which is more prominent at low trans-membrane pressure, explaining the steeper decrease observed in the 10-bar experiment. The negative rejection of $\mathrm{Na}(\mathrm{I})$, on the other hand, was ascribed to increased electro-migration of $\mathrm{Na}(\mathrm{I})$, resulting from local electrical fields, which arise when ions of different diffusivities move through $\mathrm{NF} / \mathrm{RO}$ membranes. Overall, the trend of the rejection results (as a function of the recovery ratio) is in accordance with the diffusivity rate expected from these ions, i.e., the diffusion coefficients (in $10^{-6} \mathrm{~cm}^{2} \cdot \mathrm{s}^{-1}$ ) of $\mathrm{K}(\mathrm{I})$ and $\mathrm{Na}(\mathrm{I})(19.57$ and 13.34 , respectively [27]) are higher than the diffusion coefficients of $\mathrm{Mg}$ (II) (7.06 [27]). The diffusion coefficient of $\mathrm{Ca}$ (II) is also low $\left(7.92 \times 10^{-6} \mathrm{~cm}^{2} \cdot \mathrm{s}^{-1}[27]\right)$, and its rejection was also only moderately reduced with recovery. 
Figure 3. Molar concentration ratios of $\mathrm{Na}(\mathrm{I})$ to $\mathrm{Mg}(\mathrm{II})$ (a) and $\mathrm{Cl}(-\mathrm{I})$ to $\mathrm{Mg}$ (II) (b) in brines generated at 10,18 and 28 bar ( $\Delta, \circ$ and $\square$, respectively), as a function of the recovery ratio. The $95 \%$ recovery ratio points (filled bars) are estimations based on linear extrapolation, while all other points are the measured results.
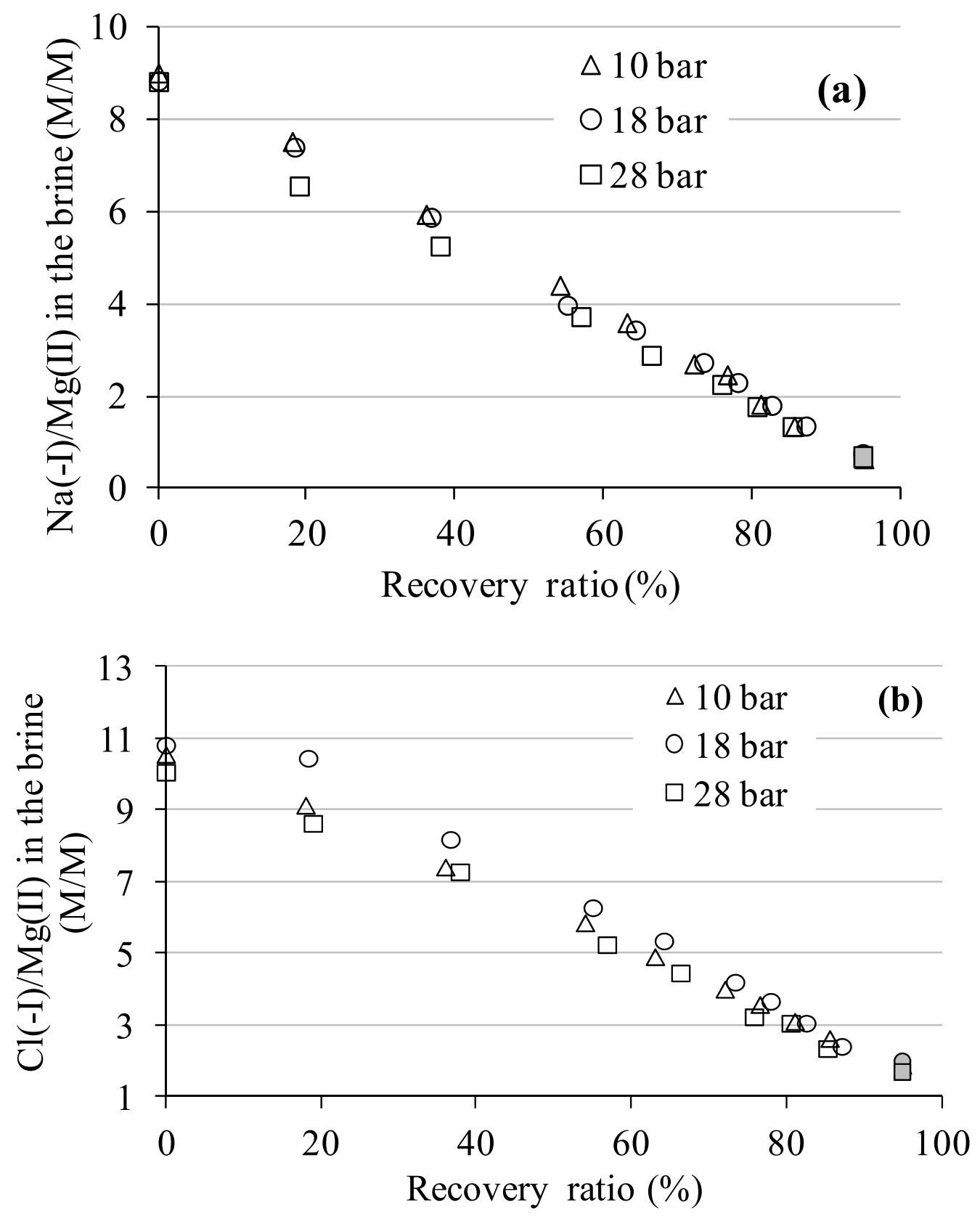

The effect of dosing the NF brine to desalinated water was studied assuming nine different scenarios: filtration at 10, 18 and 28 bar and three different dosages of brine for achieving final $\mathrm{Mg}^{2+}$ concentration of 5,10 and $20 \mathrm{mg} / \mathrm{L}$ of desalinated water. These three concentrations were chosen in order to simulate three scenarios: (1) the intended $\mathrm{Mg}^{2+}$ concentration $(5 \mathrm{mg} / \mathrm{L})$ addition at the Thames desalinated post treated water [28], which is apparently achieved by $\mathrm{MgSO}_{4}$ dosage [29]; (2) the minimum concentration recommended by the $\mathrm{WHO}$, i.e., $10 \mathrm{mg} / \mathrm{L}$; and (3) the minimum concentration recommended by the Israeli Ministry of Health, i.e., $20 \mathrm{mg} / \mathrm{L}$. All nine scenarios were calculated according to the results obtained at $85 \%$ recovery. On top of sodium and chloride ions, the addition of 
all major ions and of the antiscalant due to the NF brine dosage was calculated for the nine scenarios. The results are shown in Table 1, which shows that the overall quality of the desalinated water is hardly damaged by the addition of the brine. With respect to chloride and sodium ions, it can be concluded that their additions are not high $(<79$ and $<23 \mathrm{mg} / \mathrm{L}$, respectively, in the $20 \mathrm{mg} \mathrm{Mg} / \mathrm{L}$ case scenario) compared to background concentrations in conventional drinking water sources and compared to the addition of chlorides through the most practical technique for magnesium addition (i.e., dosage of $\mathrm{MgCl}_{2}$ ). Note that the WHO did not set a health-based guideline to chloride and sodium ions, but rather mentions a taste threshold in the range $200-300 \mathrm{mg} / \mathrm{L}$ and $\sim 200 \mathrm{mg} / \mathrm{L}$ (chloride and sodium, respectively) [30]. The addition of potassium to drinking water is generally welcome, as it is an essential element for both humans and plants [30]. The recommended daily requirement of $\mathrm{K}^{+}$is greater than $3000 \mathrm{mg}$ [30]. Thus, the addition of less than $1.2 \mathrm{mg} / \mathrm{L}$ through the dosage of the NF brine (Table 1) is not a health concern. In addition, Table 1 presents the calculated addition of the injected food grade antiscalant, which was lower than $53 \mathrm{~g} / \mathrm{L}$ for all the considered cases. This figure was calculated based on the assumptions that $3 \mathrm{mg} / \mathrm{L}$ of antiscalant are dosed to the feed stream and are totally rejected by the membrane. With respect to boron, the WHO increased the guidelines for $\mathrm{B}$ concentration in drinking water from 0.5 to $2.4 \mathrm{mg} / \mathrm{L} \mathrm{[30]}$. Therefore, the addition of $<0.011 \mathrm{mg} / \mathrm{L}$ should have no harmful effect, even in the case that the water is used for the irrigation of sensitive crops. With respect to bromide, its seawater concentration is around $80 \mathrm{mg} / \mathrm{L}$. Considering its rejection is similar to the rejection of $\mathrm{Cl}^{-}$, it can be calculated that its maximum addition would be $\sim 0.3 \mathrm{mg} / \mathrm{L}$ (assuming $20 \mathrm{mg} \mathrm{Mg} / \mathrm{L}$ target). The concentration of bromide in natural drinking water can be around $0.5 \mathrm{mg} / \mathrm{L}$ and in desalinated water $\sim 0.4 \mathrm{mg} / \mathrm{L}$ (prior to NF brine dosage, assuming $99.5 \%$ rejection in a typical SWRO step). However, a $1 \mathrm{mg} / \mathrm{L}$ concentration in desalinated water is not uncommon [30]. The only health related problem that might rise from the presence of such low bromide concentration in drinking water is the possible formation of bromates upon ozonation (the current WHO guideline is $0.01 \mathrm{mg} / \mathrm{L}$ [30]). However, the formation of bromate can be reduced by controlling the disinfection conditions. To conclude, the presence of low bromide concentration should be taken into account when choosing the applied disinfection method [30].

Regarding the addition of $\mathrm{Ca}(\mathrm{II})$, it is evident that its addition is minor compared to the background $\mathrm{Ca}$ (II) concentration, which is usually on the order of several tens of $\mathrm{mg} / \mathrm{L}$. For example, the Israeli minimal $\mathrm{Ca}(\mathrm{II})$ concentration requirement is $32 \mathrm{mg} / \mathrm{L}$ [31].

The addition of other trace metals as a consequence of dosing NF brine was assumed to be negligible, based on the following calculation: although the concentration of strontium in seawater is relatively high $(\sim 8 \mathrm{mg} / \mathrm{L})$, its measured concentrations in the brines were $23.6,23.26$ and $24.76 \mathrm{mg} / \mathrm{L}$ at 10, 18 and 28 bar, respectively. As a result, even for the highest brine dosage scenario (i.e., $20 \mathrm{mg} / \mathrm{L}$ $\mathrm{Mg}$ (II) addition) the strontium addition is negligible (Table 1). Thus, it can be safely concluded that the addition of other trace metals is also negligible. 
Table 1. The addition of ions $\left(\mathrm{Cl}^{-}, \mathrm{Na}^{+}, \mathrm{K}^{+}, \mathrm{Ca}^{2+}, \mathrm{Sr}^{2+}\right.$ and $\left.\mathrm{B}\right)$ and antiscalant agent to the desalinated water in the nine examined scenarios and the addition of $\mathrm{Cl}^{-}$for the alternative of $\mathrm{MgCl}_{2}$ dosage.

\begin{tabular}{|c|c|c|c|c|}
\hline \multirow{2}{*}{$\frac{\mathrm{Mg}^{2+} \text { addition }}{\mathrm{mg} / \mathrm{L}}$} & \multicolumn{3}{|c|}{ Applied pressure } & \multirow[t]{2}{*}{ via $\mathrm{MgCl}_{2}$ dosage } \\
\hline & 10 bar & 18 bar & 28 bar & \\
\hline \multicolumn{5}{|c|}{ Chloride ion addition (mg/L); WHO taste threshold: $200-300 \mathrm{mg} / \mathrm{L}[30]$} \\
\hline 5 & 19.6 & 19.5 & 17.4 & 14.6 \\
\hline 10 & 39.2 & 39.0 & 34.9 & 29.2 \\
\hline 20 & 78.5 & 78.1 & 69.8 & 58.4 \\
\hline \multicolumn{5}{|c|}{ Sodium ion addition $(\mathrm{mg} / \mathrm{L})$; WHO taste threshold: $200 \mathrm{mg} / \mathrm{L} \mathrm{[30]}$} \\
\hline 5 & 5.65 & 5.71 & 7.16 & \\
\hline 10 & 11.31 & 11.43 & 14.34 & \\
\hline 20 & 22.64 & 22.89 & 28.71 & \\
\hline \multicolumn{5}{|c|}{ Potassium ion addition $(\mathrm{mg} / \mathrm{L})$} \\
\hline 5 & 0.28 & 0.28 & 0.28 & \\
\hline 10 & 0.56 & 0.56 & 0.56 & \\
\hline 20 & 1.13 & 1.12 & 1.12 & \\
\hline \multicolumn{5}{|c|}{ Calcium ion addition $(\mathrm{mg} / \mathrm{L})$} \\
\hline 5 & 0.94 & 1.54 & 1.36 & \\
\hline 10 & 1.87 & 3.07 & 2.73 & \\
\hline 20 & 3.75 & 6.15 & 5.47 & \\
\hline \multicolumn{5}{|c|}{ Strontium ion addition $(\mu \mathrm{g} / \mathrm{L})$} \\
\hline 20 & 61 & 59 & 53 & \\
\hline \multicolumn{5}{|c|}{ Boron addition $(\mu \mathrm{g} / \mathrm{L})$; WHO health threshold: $2.4 \mathrm{mg} / \mathrm{L}[30]$} \\
\hline 5 & 2.58 & 2.41 & 1.73 & \\
\hline 10 & 5.16 & 4.82 & 3.46 & \\
\hline 20 & 10.33 & 9.65 & 6.94 & \\
\hline \multicolumn{5}{|c|}{ Antiscalant addition $(\mu \mathrm{g} / \mathrm{L})$} \\
\hline 5 & 13.0 & 12.7 & 11.7 & \\
\hline 10 & 26.0 & 25.4 & 23.5 & \\
\hline 20 & 52.0 & 50.8 & 47.1 & \\
\hline
\end{tabular}

\subsection{Comparison with Water Qualities Attained in Alternative Mg(II) Addition Processes}

To date, only three practical methods are available for enriching soft and desalinated water with magnesium ions: the direct dosage of magnesium-salts (either $\mathrm{MgSO}_{4}$ or $\mathrm{MgCl}_{2}$ ), as practiced, for example, in Cyprus [32] and England; dolomite $\left(\mathrm{CaMg}\left(\mathrm{CO}_{3}\right)_{2}\right)$ dissolution followed by calcite dissolution [24]; and the exchange of calcium ions with magnesium ions by means of an ion-exchanger [22]. Considering these methods solely from the water quality point of view, the following conclusions can be drawn:

1. Direct dosage can bring the concentration of $\mathrm{Mg}(\mathrm{II})$ to any required value. However, this results in a counter-ion addition ratio (relative to $\mathrm{Mg}(\mathrm{II})$ ion addition) of $1: 1\left(\mathrm{Cl}(-\mathrm{I})\right.$ or $\mathrm{SO}_{4}(-\mathrm{II})$ to $\mathrm{Mg}(\mathrm{II})$, in equivalent units). Thus, the dosage of $\mathrm{MgSO}_{4}$ can be regarded as favorable. The addition of $\mathrm{MgCl}_{2}$ is only slightly superior over the suggested method, in case the recovery ratio is below $90 \%$. In case of a $95 \%$ recovery ratio, the addition of $\mathrm{Cl}(-\mathrm{I})$ is smaller in the suggested 
process. In any event, the addition of $\mathrm{Cl}(-\mathrm{I})$ is small, relative to chloride concentrations in natural fresh water sources.

2. Dissolution of dolomite is very limited from the resultant water quality aspect [24], since its dissolution kinetics is practical only at low $\mathrm{pH}$ values, and the addition of magnesium is accompanied with calcium addition (at $\sim 1: 1$ ratio). Thus, the addition of $20 \mathrm{mg} \mathrm{Mg} / \mathrm{L}$ is impossible in the case that the water should also comply with other water quality standards, such as a minimum alkalinity threshold of $80 \mathrm{mg} / \mathrm{L}$ as $\mathrm{CaCO}_{3}$ and a dissolved calcium maximum threshold of $120 \mathrm{mg} / \mathrm{L}$ as $\mathrm{CaCO}_{3}$ [31].

3. The enrichment of water with $\mathrm{Mg}$ (II) originating from seawater by means of an ion-exchanger is a relatively flexible method [22,23,25]; however, since in this method, magnesium is exchanged with calcium, the product water quality is also somewhat limited. For example, achieving high $\mathrm{Mg}$ (II) concentrations (e.g., $20 \mathrm{mg} / \mathrm{L}$ ) will most likely be coupled with high calcium concentrations.

\subsection{Assessment of Process Cost}

From the water quality point of view, it is beneficial to operate the NF process at high pressures (i.e., 28 bars). Moreover, at low pressures, permeate and brine fluxes are reduced, and $\operatorname{Mg}($ II) rejections deteriorate; therefore, a larger NF plant will be required, resulting in increased capital costs. Capital costs are a significant cost component in the suggested process (Table 2). On the other hand, the operation of the plant at low pressures results in lower operational costs. Thus, in order to decide upon the most cost-effective pressure, the optimization of the cost assessment should be conducted. Since this was out of the scope of the current work, the cost assessment is given here only for operation at the two higher pressures (i.e., 18 and 28 bar), while the cost of operating at 10 bar is not shown, since from the water quality aspect, there was no incentive to decreasing the pressure to this value. Moreover, the permeate flux attained at high recovery in the 10 bar operation case was impractically low $\left(<10^{-6} \mathrm{~m} \cdot \mathrm{s}^{-1}\right)$.

The main component of the cost of the presented process is the energy required in the NF step. However, in the cost assessment, the addition of antiscalant, the UF step (Figure 1) and the capital expenses (CAPEX) were also calculated (Table 2). The following assumptions were used in the cost assessment procedure: electricity price of $0.068 \$ /(\mathrm{kW} \cdot \mathrm{h})$; electricity consumption of $40 \mathrm{~W} \cdot \mathrm{h}$ per bar per pumping per $\mathrm{m}^{3}$ of feed; antiscalant price $\$ 2,000$ per ton; antiscalant dosage of $3 \mathrm{mg} / \mathrm{L}$ to the feed; $85 \%$ recovery. The cost of the UF step was calculated based on the average UF filtrate cost of $\$ 0.8$ cent per $\mathrm{m}^{3}$ of the filtrate [33]. Capital expenses (CAPEX) were calculated assuming 5\% interest and a 20-year serviceable lifetime; a cost of $\$ 2,500 \mathrm{~m}^{-3}$ feed $\mathrm{h}$ (regardless of the pressure); and a desalination plant capacity of $100 \mathrm{Mm}^{3}$ per year. Note that in the assessment of the CAPEX, the enlargement of the NF plant (i.e., number of membranes) required due to the reduced flux at the lower pressure scenario was neglected. Instead, Table 2 presents that in the case that the CAPEX of the 18-bar operation is twice the CAPEX of the 28-bar one (values given in brackets in the last two rows), the total costs of the 18-bar scenarios are practically the same as those of the 28-bar scenarios.

The costs of separating $1 \mathrm{~kg}$ of $\mathrm{Mg}$ (II) by the process in the 18- and 28-bar scenarios are $\$ 0.053$ and $\$ 0.070$, respectively, while in the case that the CAPEX of the 18-bar scenarios are doubled; the total cost of $1 \mathrm{~kg} \mathrm{Mg}(\mathrm{II})$ becomes $\$ 0.074$. Note that the figures in Table 2 are almost proportional to the 
mass of $\mathrm{Mg}(\mathrm{II})$ added to the desalinated water, for a given pressure. Nevertheless, there are small differences between the calculated costs, but since these differences are of the order of $\sim 10^{-4}$ cents, they are not noticeable in the Table.

As mentioned before, the energy required for the NF stage is the main cost component, comprising $50.7 \%$ and $61.5 \%$ of the overall cost in the 18 -bar and 28 -bar scenarios, respectively. The second main component is the CAPEX, which constitutes $39.2 \%$ and $30.6 \%$ of the overall cost, in the 18- and 28-bar cases, respectively.

Table 2. Estimation of the operational cost components and capital costs (cents per $\mathrm{m}^{3}$ of desalinated water) associated with the presented process, for six different case studies.

\begin{tabular}{ccccccc}
\hline Pressure & \multicolumn{3}{c}{$\mathbf{1 8}$ bar } & \multicolumn{3}{c}{$\mathbf{2 8}$ bar } \\
\hline $\mathrm{Mg}(\mathrm{II})$ addition (mg/L) & 5 & 10 & 20 & 5 & 10 & 20 \\
\hline Antiscalant & $2.2 \times 10^{-3}$ & $4.5 \times 10^{-3}$ & $9.0 \times 10^{-3}$ & $2.3 \times 10^{-3}$ & $4.6 \times 10^{-3}$ & $9.3 \times 10^{-3}$ \\
NF energy & 0.013 & 0.027 & 0.054 & 0.022 & 0.043 & 0.086 \\
UF energy & $4.5 \times 10^{-4}$ & $8.9 \times 10^{-4}$ & $1.8 \times 10^{-3}$ & $4.6 \times 10^{-4}$ & $9.3 \times 10^{-4}$ & $1.9 \times 10^{-3}$ \\
Total OPEX & 0.016 & 0.032 & 0.064 & 0.024 & 0.049 & 0.098 \\
CAPEX $^{\mathrm{a}}$ & 0.010 & 0.021 & 0.042 & & & \\
& $(0.021)$ & $(0.042)$ & $(0.083)$ & 0.011 & 0.021 & 0.043 \\
Total cost $^{\mathrm{b}}$ & 0.026 & 0.053 & 0.106 & & & \\
& $(0.037)$ & $(0.074)$ & $(0.148)$ & 0.035 & 0.070 & 0.141 \\
\hline
\end{tabular}

Notes: ${ }^{a}$ values in brackets represent the elevated CAPEX due to the required enlargement of the NF plant in the low pressure (i.e., low flux) scenarios; ${ }^{b}$ values in brackets represent the elevated total costs due to the doubled CAPEX in the low pressure scenarios.

The cost of adding $\mathrm{Mg}(\mathrm{II})$ to desalinated water by means of dosing NF brine is approximately one order of magnitude lower than any other available $\mathrm{Mg}$ (II) enrichment method. However, it should be recognized that the water quality attained in each process is different (see Section 3.2); therefore, straightforward comparison of the cost does not reveal the complete picture. The prices of the $\mathrm{Mg}$ salts, $\mathrm{MgCl}_{2}$ and $\mathrm{MgSO}_{4} \cdot 7 \mathrm{H}_{2} \mathrm{O}$, are $\sim \$ 300$ and $\sim \$ 275$ per ton chemical, respectively [18]. Thus, enriching the water with $10 \mathrm{mg} \mathrm{Mg} / \mathrm{L}$, through direct dosage of $\mathrm{MgCl}_{2}$ or $\mathrm{MgSO}_{4} \cdot 7 \mathrm{H}_{2} \mathrm{O}$, will cost 1.18 and 2.06 cents per $\mathrm{m}^{3}$ desalinated water, respectively. The costs associated with the other two alternatives, i.e., the dolomite-calcite dissolution process and the ion exchange dissolution process, could not be easily distinguished from the cost of the overall post-treatment processes; thus, the following figures are merely an assessment of the overall cost of adding $12.15 \mathrm{mg} \mathrm{Mg} / \mathrm{L}$ in the dolomite and the ion exchange processes: 0.53 and 0.51 cents per $\mathrm{m}^{3}$ of product water, respectively [18], i.e., one order of magnitude higher than the addition of $10 \mathrm{mg} \mathrm{Mg} / \mathrm{L}$ by the suggested process.

\section{Conclusions}

The enhancement of a method for enriching desalinated and soft water with $\mathrm{Mg}$ (II) ions is presented. The method is based on passing seawater through an NF membrane (DS DL5) and the dosage of the $\mathrm{Mg}(\mathrm{II})$-rich brine in the desalinated water.

The new results show that elevating the pressure from 10 to 18 bar significantly affected the $\operatorname{Mg}$ (II) rejection values. However, further elevation of the pressure to 28 bar improved the rejection values 
only slightly. The NF brine was characterized by high $\mathrm{Mg}$ (II) concentrations of 7.707, 7.829 and $8.520 \mathrm{~g} / \mathrm{L}$ applying $85 \%$ recovery at 10,18 and 28 bar, respectively. The $\mathrm{Mg}(\mathrm{II}): \mathrm{Na}(\mathrm{I})$ concentration ratios were significantly reduced when the recovery ratios were elevated, while they were hardly affected by the applied pressure. Therefore, in areas in which stringent upper thresholds for $\mathrm{Na}(\mathrm{I})$ and $\mathrm{Cl}(-\mathrm{I})$ are forced, the brine generated at higher recovery ratios is considered more adequate for enriching soft waters with $\mathrm{Mg}(\mathrm{II})$.

The cost of the process was found to be approximately one order of magnitude lower than the cost of replenishing $\mathrm{Mg}(\mathrm{II})$ by alternative methods.

\section{Acknowledgments}

This project was funded by the Israel Science Foundation (\#504/10) and the Joint German-Israeli Water Technology Research Program (BMBF/MOST) (research \#2018807).

\section{Author Contributions}

The three authors contributed evenly to the execution of the experiments and the writing of this paper.

\section{Conflicts of Interest}

The authors declare no conflict of interest.

\section{References}

1. Cotruvo, J.; Bartram, J., Eds. Calcium and Magnesium in Drinking Water: Public Health Significance, 1st ed.; World Health Organization Press: Geneva, Switzerland, 2009; Chapters 5-10.

2. Rosanoff, A.; Weaver, C.M.; Rude, R.K. Suboptimal Magnesium Status in the United States: Are the Health Consequences Underestimated? Nutr. Rev. 2012, 70, 153-164.

3. Sinclair, M.; Hayes, P. Desalination Decision for Israel. Health Stream, 2011, 61, 4-6. Available online: http://www.waterra.com.au/publications/document-search/?download=128 (accessed on 24 April 2014).

4. Chiu, H.; Tsai, S.; Wu, T.; Yang, C. Effect Modification of the Association between Trihalomethanes and Pancreatic Cancer by Drinking Water Hardness: Evidence from an Ecological Study. Environ. Res. 2010, 110, 513-518.

5. Kuo, H.; Peng, C.; Feng, A.; Wu, T.; Yang, C. Magnesium in Drinking Water Modifies the Association between Trihalomethanes and the Risk of Death from Colon Cancer. J. Toxicol. Env. Health Part A Curr. Issues 2011, 74, 392-403.

6. Liao, Y.; Chen, P.; Chiu, H.; Yang, C. Magnesium in Drinking Water Modifies the Association between Nitrate Ingestion and Risk of Death from Esophageal Cancer. J. Toxicol. Env. Health Part A Curr. Issues 2013, 76, 192-200. 
7. Chiu, H.; Kuo, C.; Tsai, S.; Chen, C.; Wu, D.; Wu, T.; Yang, C. Effect Modification by Drinking Water Hardness of the Association between Nitrate Levels and Gastric Cancer: Evidence from an Ecological Study. J. Toxicol. Env. Health Part A Curr. Issues 2012, 75, 684-693.

8. Cheng, M.; Chiu, H.; Tsai, S.; Chen, C.; Yang, C. Calcium and Magnesium in Drinking-Water and Risk of Death from Lung Cancer in Women. Magnes. Res. 2012, 25, 112-119.

9. Dahl, C.; Søgaard, A.J.; Tell, G.S.; Flaten, T.P.; Hongve, D.; Omsland, T.K.; Holvik, K.; Meyer, H.E.; Aamodt, G. Nationwide Data on Municipal Drinking Water and Hip Fracture: Could Calcium and Magnesium be Protective? A NOREPOS Study. Bone 2013, 57, 84-91.

10. Rasic-Milutinovic, Z.; Perunicic-Pekovic, G.; Jovanovic, D.; Gluvic, Z.; Cankovic-Kadijevic, M. Association of Blood Pressure and Metabolic Syndrome Components with Magnesium Levels in Drinking Water in some Serbian Municipalities. J. Water Health 2012, 10, 161-169.

11. Howarth, M.; Riva, A.; Marks, P.; Williams, R. Association of Water Softness and Heavy Alcohol Consumption with Higher Hospital Admission Rates for Alcoholic Liver Disease. Alcohol Alcohol. 2012, 47, 688-696.

12. Luo, J.; Zhao, Q.; Zhang, L.; Qiu, Z.; Liu, L.; Chen, J.; Zeng, H.; Huang, Y.; Tan, Y.; Yang, L.; et al. The Consumption of Low-Mineral Bottled Water Increases the Risk of Cardiovascular Disease: An Experimental Study of Rabbits and Young Men. Int. J. Cardiol. 2013, 168, 4454-4456.

13. Spungen, J.H.; Goldsmith, R.; Stahl, Z.; Reifen, R. Desalination of Water: Nutritional Considerations. Isr. Med. Assoc. J. 2013, 15, 230-234.

14. Ben-Gal, A.; Yermiyahu, U.; Cohen, S. Fertilization and Blending Alternatives for Irrigation with Desalinated Water. J. Environ. Qual. 2009, 38, 529-536.

15. Yermiyahu, U.; Tal, A.; Ben-Gal, A.; Bar-Tal, A.; Tarchitzky, J.; Lahav, O. Environmental Science-Rethinking Desalinated Water Quality and Agriculture. Science 2007, 318, 920-921.

16. Rosanoff, A. Changing Crop Magnesium Concentrations: Impact on Human Health. Plant Soil 2013, 368, 139-153.

17. Lahav, O.; Kochva, M.; Tarchitzky, J. Potential Drawbacks Associated with Agricultural Irrigation with Treated Wastewaters from Desalinated Water Origin and Possible Remedies. Water Sci. Technol. 2010, 61, 2451-2460.

18. Telzhensky, M.; Birnhack, L.; Lehmann, O.; Windler, E.; Lahav, O. Selective Separation of Seawater $\mathrm{Mg}^{2+}$ Ions for use in Downstream Water Treatment Processes. Chem. Eng. J. 2011, 175, $136-143$.

19. Arkhangelsky, E.; Gitis, V. Effect of Transmembrane Pressure on Rejection of Viruses by Ultrafiltration Membranes. Sep. Purif. Technol. 2008, 62, 619-628.

20. Genesys International. Available online: http://www.Genesysro.Com/Index.Php (accessed on 24 April 2014).

21. Lahav, O.; Telzhensky, M.; Zewuhn, A.; Gendel, Y.; Gerth, J.; Calmano, W.; Birnhack, L. Struvite Recovery from Municipal-Wastewater Sludge Centrifuge Supernatant using Seawater NF Concentrate as a Cheap mg(II) Source. Sep. Purif. Technol. 2013, 108, 103-110.

22. Birnhack, L.; Lahav, O. A New Post-Treatment Process for Attaining $\mathrm{Ca}^{2+}, \mathrm{Mg}^{2+} \mathrm{SO}_{4}{ }^{2-}$ and Alkalinity Criteria in Desalinated Water. Water Res. 2007, 41, 3989-3997. 
23. Birnhack, L.; Shlesinger, N.; Lahav, O. A Cost Effective Method for Improving the Quality of Inland Desalinated Brackish Water Destined for Agricultural Irrigation. Desalination 2010, 262, 152-160.

24. Birnhack, L.; Fridman, N.; Lahav, O. Potential Applications of Quarry Dolomite for Post Treatment of Desalinated Water. Desalination Water Treat. 2009, 1, 58-67.

25. Birnhack, L.; Oren, S.; Lehmann, O.; Lahav, O. Development of an Additional Step to Current $\mathrm{CO}_{2}$-Based $\mathrm{CaCO}_{3(\mathrm{~s})}$ Dissolution Post-Treatment Processes for Cost-Effective $\mathrm{Mg}^{2+}$ Supply to Desalinated Water. Chem. Eng. J. 2010, 160, 48-56.

26. Clesceri, L.S. Standard Methods for the Examination of Water and Wastewater, 20th ed.; Clesceri, L.S., Eaton, A.D., Greenberg, A.E., Eds; American Public Health Association: Washington, DC, USA, 1998; pp. 874.

27. Vanysek, P. Ionic conductivity and diffusion at infinite dilution. In CRC Handbook of Chemistry and Physics, 94th ed.; Haynes, W.M. Ed.; CRC Press/Taylor and Francis: Boca Raton, FL, USA, 2013; pp. 5-77.

28. Thames Gateway Water Treatment Works-An Engineering Solution. Available online: http://www.thameswater.co.uk/your-account/10285.html (accessed on 24 April 2014).

29. Acciona-Aqua. Available online: http://www.acciona-agua.com/activities/desalination/becktondesalination-plant.aspx?actividad $=0$ (accessed on 24 April 2014).

30. Guidelines for Drinking Water-Quality, 4th ed.; Sheffer, M., Ed.; World Health Organization (WHO): Geneva, Switzerland, 2011; pp. 564.

31. Lahav, O.; Birnhack, L. Quality Criteria for Desalinated Water Following Post-Treatment. Desalination 2007, 207, 286-303.

32. Marangou, V.; Savvides, K. First Desalination Plant in Cyprus-Product Water Aggresivity and Corrosion Control. Desalination 2001, 138, 251-258.

33. Bu-Rashid, K.A.; Czolkoss, W. Pilot Tests of Multibore UF Membrane at Addur SWRO Desalination Plant, Bahrain. Desalination 2007, 203, 229-242.

(C) 2014 by the authors; licensee MDPI, Basel, Switzerland. This article is an open access article distributed under the terms and conditions of the Creative Commons Attribution license (http://creativecommons.org/licenses/by/3.0/). 